\title{
Productivity Improvement of the Concrete Construction Work
}

\author{
S. Sasaki, Y. Uno, S. Hashimoto, and S. Date
}

\begin{abstract}
NATM (New Austrian Tunneling Method) is the typical construction method for the tunnel. Generally, inside of the tunnel shall be covered by lining concrete. The form work of the concrete will be removed when the concrete achieve enough strength. In other words, next step of construction cannot be conducted during this concrete curing period. Hence acceleration of curing of the concrete makes reduction of construction period possible. On the other hand, various special admixtures of which gives an effect of acceleration of cement hydration, were released to construction market, so far.

In this study, influence of dosing various admixtures into the concrete on an improvement of concrete properties was focused on to accelerate tunnel construction work. As a result, from the viewpoint of productivity improvement of the concrete construction, it was confirmed that the use of appropriate accelerator allowed both reduction of construction period and quality improvement.
\end{abstract}

Index Terms-NATM, admixture, hydration, concrete lining, accelerator.

\section{INTRODUCTION}

Recently, various design proposal, attempting the differentiation with the competitors, are being provided to successful bid of the construction work Productivity improvement technology to enable shortening of construction period and excellent both quality and durability in which making the construction work to be maintenance-free are being desired as well. The approach from the aspects such as structure, a design, construction, and materials to improve productivity of the concrete construction can be considered too. For instance, the application of pre-cast products, adoption of the pre-cast structure, the strength promotion of the concrete are effective on shortening of the term of works.

On the other hand, NATM is construction method in which the demolding work will be carried out when strength of the concrete is still $2 \sim 3 \mathrm{~N} / \mathrm{mm}^{2}$ at 10 hours after casting of concrete lining [1], [2]. This construction method is the typical case that the improvement of the early strength of the concrete leads to productivity improvement [3]-[6].

In this study, acceleration of hydration speed was focused on to improve strength development of the concrete for optimization of the construction work.

Manuscript received November 30, 2014; revised February 27, 2015.

S. Sasaki and S. Date are with Course of Civil Engineering, School of Engineering, Tokai University, Japan (e-mail: 4bcdm003@mail.tokai-u.jp).

Y. Uno is with Dept. of Civil Engineering, Technical Research Institute, Sato Kogyo Co., Ltd., Japan.

S. Hashimoto is with Dept. of Civil Engineering, Faculty of Engineering, Fukuoka University, Japan.
From the viewpoints of circular economy and sustainable development, Portland Blast-furnace slag cement is used on a wide range in Japan .However, disadvantage of Portland Blast-furnace slag cement of initial strength is low [6].

Regarding, experiment investigations on using the accelerator of CSH system to accelerate the hydration of blast furnace slag, improvement of the strength is indicated by CSH initial hydration reaction [7]-[9]. And influence of mixture materials on a hardening process of the concrete [10].

It is undesirable for both quality and durability of hardened concrete to be spoiled by giving priority to strength development. Hence use of high early strength cement and curing at high temperature were avoided.

In this study, intended for experimental examination progressively to improve productivity of the concrete construction an application method to relatively perform de-model at low strength represented by lining concrete construction in NATM. Furthermore, this study is advocated which carried out satisfy numerical target (compressive strength at age of 10 hours: $3 \mathrm{~N} / \mathrm{mm}^{2}$ ) which set concretely. The effective method can be suggested based on the result that inspected the combination of materials to satisfy aim compressive strength.

\section{METHOD OF EXPERIMENT}

\section{A. Outline or Experiment}

First of all, it was fundamental research [6] of the degree that this study aimed for the confirmation of materials properties. The situation included a change at a stage to push forward experimental examination, and is for the application study assuming which used in the specific tunnel construction field. Therefore concrete numerical target was set, and materials used were changed progressively in comparison with an original experiment condition. The experimental examination was carried out with three phases, and was distinguished each from experiment I experiment II, fundamental experiment III. There are shown a study flow in Fig. 1.

Case I: To be verified the difference in strength development properties of the concrete was inspected, and was chosen some materials which an improvement effect of the initial strength development could expect. Including the case was different from the original purpose of use.

Case II: To be verified the difference in strength development properties of the concrete changed the use materials the difference and was carried out to satisfy numerical target (compressive strength at the age of 10 hours: 
$3 \mathrm{~N} / \mathrm{mm}^{2}$ ) which was set concretely caused of the rapid construction of the lining concrete in the specific tunnel construction site.

Case III: To be verified the difference in strength development properties of the concrete, The use materials were changed to the thing same as the plant which supplies Ready mixed concrete to the tunnel construction field undertaking construction. And numerical target was not changed (compressive strength at the age of 10hours was $3 \mathrm{~N} / \mathrm{mm}^{2}$ ).

\section{B. Selection of Candidate Materials (Case I)}

It is one of the methods to realize the safe improvement in the demolding and the prevention of the initial defect to accelerate initial strength development of the lining concrete, in recent tunnel construction. Therefore [5] that has been conducted many studies including the evaluation of the influence of caring method on initial strength development of the concrete so far. However, in this study, the materials in which an effect of an improvement of the initial strength development can be expected were nominated. Furthermore, at the view point of prevention of deterioration of the durability and long term strength, both use of high early strength cement and high temperature curing were avoided. In addition, temperature at the mixing and the curing were strictly controlled in $20 \pm 2^{\circ} \mathrm{C}$.

\footnotetext{
CASE I ( Selection of materials)

Assuming the lining concrete placement in NATM

And selecting an improved effect can be expected in the initial material Strength

To verify the difference of strength development characteristics (Basic research)

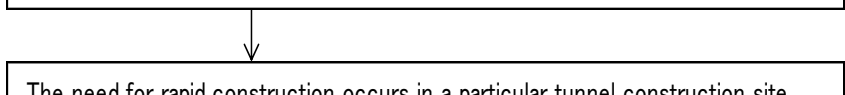

The need for rapid construction occurs in a particular tunnel construction site

CASE II (Simulation test)
Targeting: Age of 10 hours in the compressive strength $3 \mathrm{~N} / \mathrm{mm}^{2}$
To verify the difference of strength development characteristics (Applied research)
CASE II (On site Confirmation test)
Use the material of the plant supplying the concrete to the construction
To verify the difference of strength development characteristics (Applied research)

Fig. 1. Procedure of experiment.

\section{1) Materials and mix proportions}

The materials used in this experiment and Mix proportions are shown in Table I and Table I respectively. The cement of the base assumed Portland Blast-furnace slag cement in reference to combination (24-15-40BB) for tunnel lining concrete. Special admixture such as corrosion inhibitor can be expected as strength enhancer, major ingredient of this material is calcium nitrite of which makes hydration of tri-calcium silicate $(3 \mathrm{CaO} \cdot \mathrm{SiO} 2$, here in after "C3S") accelerate by the function of nitrite ion. There are two grades of the fineness in calcium oxide based expansive agent. The fineness of normal one is $3,410 \mathrm{~cm}^{2} / \mathrm{g}$ : hydration accelerator materials (here in after "EX") is $4,520 \mathrm{~cm}^{2} / \mathrm{g}$. It can be assumed that the hydration speed of EX might be faster than the other one.
}

The mix proportion of $\mathrm{W} / \mathrm{C}$ was controlled as $54.9 \%$ and the dosage of the admixture were changed. Case I - (3) was based on Case I-(2). The quantity of dosage of the highperformance water-reducing agent was regulated for necessary slump of the manufacture of the concrete test specimen. The fresh property did not standardize in Case I, because even though the dosage increases, the initial strength may not be influenced. In Case I-(3) was expected that slump becomes small more than Case I-(2). The quantity of dosage of HPWR was increased for $0.1 \%$ of quantity of unit cement. The Corrosion inhibitor was also put in mixing water.

TABLE I: MATERIALS USED

\begin{tabular}{|c|c|c|}
\hline \multicolumn{2}{|c|}{ Materials } & Properties \\
\hline Cement & B & $\begin{array}{l}\text { Portland Blast-furnace slag cement : } \\
\text { Density* } 3.04 \mathrm{~g} / \mathrm{cm}^{3}\end{array}$ \\
\hline \multirow{2}{*}{$\begin{array}{l}\text { Fine } \\
\text { aggregate }\end{array}$} & $\mathrm{S} 1$ & $\begin{aligned} \text { Crushed sand } & \text { from Sagamihara : Density } \\
& * 2.63 \mathrm{~g} / \mathrm{cm}^{3}\end{aligned}$ \\
\hline & $\mathrm{S} 2$ & $\begin{array}{l}\text { Kimitsu Ubuyama sand: } \\
\text { Density }{ }^{*} 2.57 \mathrm{~g} / \mathrm{cm}^{3}\end{array}$ \\
\hline Aggregate & G1 & $\begin{array}{c}\text { Crushed stone from Sagamihara-shi;2005: } \\
\text { Density }{ }^{*} 2.66 \mathrm{~g} / \mathrm{cm}^{3}\end{array}$ \\
\hline \multirow{2}{*}{ Admixture } & EX & $\begin{array}{l}\text { Hydration accelerator materials : Density } \\
\qquad 3.19 \mathrm{~g} / \mathrm{cm}^{3} \text {, (Lime) }\end{array}$ \\
\hline & SM & $\begin{array}{l}\text { High-strength materials : Density } \\
2.93 \mathrm{~g} / \mathrm{cm}^{3}: \text { (Anhydrite) }\end{array}$ \\
\hline \multirow{2}{*}{$\begin{array}{l}\text { Chemical } \\
\text { admixture }\end{array}$} & $\mathrm{CN}$ & $\begin{array}{l}\text { Corrosion inhibitor ; Density } 1.27 \mathrm{~g} / \mathrm{cm}^{3} \text { : } \\
\text { (Nitrous acid) }\end{array}$ \\
\hline & HPWR & $\begin{array}{c}\text { Hight-performance water-reducing agent } \\
\text { (type of AE) :(Lignin sulfonic acid } \\
\text { compound) }\end{array}$ \\
\hline
\end{tabular}

Hydration accelerator and high-strength materials were poured and mixed into the mixing water in advance.

\section{2) Items of experiment}

Influence of dosing various admixture into the concrete on the performances such the fresh property, mechanical properties, drying shrinkage were investigated in this experiment. Slump test (JIS A 1101, Determination of air content of freshly mixed concrete-Pressure method (JIS A 1128), Method of test for time of setting of concrete mixtures by penetration resistance (JIS A 1147), Compressive strength test (JIS A 1108:at 18hours, 24hours, 7days, 28days) , methods of measurement for length change of mortar and concrete-Part 3:Method with dial gauge (JIS A 1129-3, The dry period until 38 weeks) were conducted respectively.

\section{Simulation Test (Case II)}

To enable an early demolding of the lining concrete was requested in tunnel construction undertaking construction, desired strength of $3 \mathrm{~N} / \mathrm{mm}^{2}$ was set to be concrete in materials age 10 hours. Based on the knowledge that got from Case I, materials used were changed so that an improvement effect of the initial strength development expected it. Construction site in the tunnel was expected concerned for 
Construction site in the tunnel was expected concerned for the winter season. In addition, the mixing and the curing of the test specimen were carried out in $15 \pm 2^{\circ} \mathrm{C}$ and humidity of atmosphere was controlled to $65 \% \mathrm{RH}$.

TABLE II: MIX PROPORTIONS (CASE I)

\begin{tabular}{|c|c|c|c|c|c|c|c|c|c|c|c|c|}
\hline \multirow{2}{*}{ Case } & \multirow[t]{2}{*}{$\mathrm{W} / \mathrm{C}(\%)$} & \multirow{2}{*}{$\begin{array}{l}\text { Air } \\
(\%)\end{array}$} & \multirow{2}{*}{$\begin{array}{c}\mathrm{s} / \mathrm{a} \\
(\%)\end{array}$} & \multicolumn{9}{|c|}{ Unit weight $\left(\mathrm{kg} / \mathrm{m}^{3}\right)$} \\
\hline & & & & $\mathrm{W}$ & $\mathrm{C}$ & EX & SM & $\mathrm{S} 1$ & S2 & G1 & $\mathrm{CI}$ & Ad1 \\
\hline I - (1) & \multirow{4}{*}{54.9} & \multirow{4}{*}{4.5} & \multirow{2}{*}{45.0} & \multirow{4}{*}{$\begin{array}{c}16 \\
8\end{array}$} & \multirow{4}{*}{$\begin{array}{c}30 \\
6\end{array}$} & 0 & 0 & \multirow{2}{*}{565} & \multirow{2}{*}{242} & \multirow{4}{*}{1003} & 0 & \multirow{3}{*}{3.1} \\
\hline I -(2) & & & & & & 0 & 0 & & & & 7.6 & \\
\hline I -3) & & & 44.6 & & & 20 & 0 & 554 & 237 & & 0 & \\
\hline I -(4) & & & 44.1 & & & 0 & 31 & 545 & 233 & & 0 & 3.4 \\
\hline
\end{tabular}

\section{1) Materials and mix proportion}

Materials used are shown in Table III. Mix proportions are shown in Table IV. Portland Blast-furnace slag cement (here in after "BB"), the blended cement, was used for Case I series, but in this series, cement had been changed from BB to Ordinary Portland Cement (here in after "OPC") expecting initial strength improvement. In addition, among the admixture used in Case I, EX of which were evaluated to be superior including quality after hardening except the initial strength development. Furthermore, in Case II, the combination of hydration accelerator (here in after "HA") and high-range water-reducing agent were adopted as an additives. This is a combination developed for concrete products. Curing time until demolding can be reduced by giving initial strength development characteristics. As the result, an improvement of the productivity in the concrete product factory will be expected by shortening of the cycle time of concrete lining work. As for the hydration accelerator, major ingredient is nanoparticles of the calcium silicate hydrate (C-S-H). This particle acts as a nucleus of the hydrate and promotes hydration reaction. It has the new hardening promotion mechanism that initial strength of the concrete can be improved.

Therefore it became the minute concrete with the seed crystal, and the durability was improved when the HA had been used. However, there are not the results that applied to tunnel lining concrete construction so far. In addition, confirmation was performed by an effect because neither the quantity of unit cement nor the example and was examined by around $300 \mathrm{~kg} / \mathrm{m}^{3}$ of concrete combination no existed.

In this mix proportion, W/C had been set as same as a mix standard (24-15-40BB) for lining concrete. Target value of the slump and air content were set to $15 \mathrm{~cm}$ and $4.5 \%$ respectively.

\section{Items experiment}

Slump, air content, and compressive strength at the age of 10hours, 12 hours were conducted respectively.

\section{On site Confirmation Test (Case III)}

With materials same as the plant which supplied lady mixed concrete to the tunnel construction site undertaking construction concerned, it was tested again. The manufacture and caring of the test specimen that the experiment was conducted in the examination room of the plant concerned maintained environment of $22 \pm 2{ }^{\circ} \mathrm{C}$.

TABLE III: MATERIAL USED (CASE II)

\begin{tabular}{|c|c|c|}
\hline \multicolumn{2}{|c|}{ Material } & Properties \\
\hline Cement & $\mathrm{C}$ & $\begin{array}{l}\text { Ordinary portland cement : Density } \\
3.16 \mathrm{~g} / \mathrm{cm}^{3}\end{array}$ \\
\hline $\begin{array}{c}\text { Fine } \\
\text { aggregate }\end{array}$ & $\mathrm{S} 2$ & $\begin{array}{l}\text { Kimitsu Ubuyama sand : Density }{ }^{*} \\
2.57 \mathrm{~g} / \mathrm{cm}^{3}\end{array}$ \\
\hline Aggregate & G1 & $\begin{array}{c}\text { Crashed stone from } \\
\text { Sagamihara-shi(2005) : Density* } \\
2.66 \mathrm{~g} / \mathrm{cm}^{3}\end{array}$ \\
\hline Admixture & EX & $\begin{array}{l}\text { Hydration accelerator materials :Density } \\
3.19 \mathrm{~g} / \mathrm{cm}^{3}, \quad \text { (Lime) }\end{array}$ \\
\hline \multirow[b]{2}{*}{$\begin{array}{l}\text { Chemical } \\
\text { admixture }\end{array}$} & HA & Hydration accelerator: $(\mathrm{C}-\mathrm{S}-\mathrm{H})$ \\
\hline & HRWRA & $\begin{array}{l}\text { High-range water-reducing agent (type } \\
\qquad \text { AE): (PAE compound) }\end{array}$ \\
\hline
\end{tabular}

TABLE IV: MIX PROPORTIONS(CASE II)

\begin{tabular}{|c|c|c|c|c|c|c|}
\hline \multicolumn{2}{|c|}{ Case } & \multicolumn{2}{|c|}{$\mathrm{W} / \mathrm{C}(\%)$} & \multicolumn{2}{|c|}{$\operatorname{Air}(\%)$} & $\mathrm{s} / \mathrm{a}(\%)$ \\
\hline \multicolumn{2}{|c|}{ II - (1) } & \multirow{2}{*}{\multicolumn{2}{|c|}{54.0}} & \multirow{2}{*}{\multicolumn{2}{|c|}{4.5}} & \multirow{2}{*}{45.0} \\
\hline & & & & & & \\
\hline \multicolumn{7}{|c|}{ Unit weight $\left(\mathrm{kg} / \mathrm{m}^{3}\right)$} \\
\hline $\mathrm{W}$ & $\mathrm{C}$ & EX & $\mathrm{S} 2$ & G1 & $\mathrm{HA}$ & HRWRA \\
\hline \multirow{2}{*}{160} & 296 & 0 & \multirow{2}{*}{810} & \multirow{2}{*}{1027} & \multirow{2}{*}{11.84} & \multirow{2}{*}{8.88} \\
\hline & 261 & 35 & & & & \\
\hline
\end{tabular}

TABLE V: MATERIALS USED (CASE III)

\begin{tabular}{|c|c|c|}
\hline \multicolumn{2}{|c|}{ Materials } & Properties \\
\hline Cement & $\mathrm{C}$ & $\begin{array}{c}\text { Ordinary portland cement : Density } \\
3.16 \mathrm{~g} / \mathrm{cm}^{3}\end{array}$ \\
\hline \multirow{2}{*}{$\begin{array}{c}\text { Fine } \\
\text { aggregate }\end{array}$} & S3 & $\begin{array}{c}\text { Kyoto Yura River land sand } \\
\text { : Density }{ }^{*} 2.56 \mathrm{~g} / \mathrm{cm}^{3}\end{array}$ \\
\hline & $\mathrm{S} 4$ & $\begin{array}{c}\text { Ubuyama Kyotango sand : Density* } \\
2.54 \mathrm{~g} / \mathrm{cm}^{3}\end{array}$ \\
\hline \multirow{3}{*}{ Aggregate } & $\mathrm{G} 2$ & $\begin{array}{c}\text { Crushed stone from Kameoka (4020) : } \\
\text { Density* } 2.67 \mathrm{~g} / \mathrm{cm}^{3}\end{array}$ \\
\hline & G3 & $\begin{array}{c}\text { Crushed stone from Kameoka (2015) : } \\
\text { Density } * 2.67 \mathrm{~g} / \mathrm{cm}^{3}\end{array}$ \\
\hline & G4 & $\begin{array}{c}\text { Crushed stone from Kameoka (1505) : } \\
\text { Density } * 2.67 \mathrm{~g} / \mathrm{cm}^{3}\end{array}$ \\
\hline Admixture & EX & $\begin{array}{l}\text { Hydration accelerator materials:Density } \\
3.19 \mathrm{~g} / \mathrm{cm}^{3}, \quad \text { (Lime) }\end{array}$ \\
\hline \multirow{5}{*}{$\begin{array}{l}\text { Chemical } \\
\text { admixture }\end{array}$} & HA & Hyderation accelerator. : (C-S-H) \\
\hline & HRWR & $\begin{array}{l}\text { High-range water-reducing agent : } \\
\text { (Compound PAE ) }\end{array}$ \\
\hline & WRA & $\begin{array}{c}\text { Water-reducing agent(type of AE): } \\
\text { (Lignin sulfonate and oxycarboxylate) }\end{array}$ \\
\hline & HPWRA & $\begin{array}{l}\text { High-performance water-reducing } \\
\text { agent(type of AE):(Lignin sulfonate and } \\
\text { oxycarboxylic acid-based compound) }\end{array}$ \\
\hline & & \\
\hline
\end{tabular}

*:in saturated surface-dry condition 


\section{3) Materials and mix proportion}

Materials used are shown in Table V. Mix proportions are shown in Table VI. Based on a result of Case II, the additive was strong agent and high-range water-reducing agent, the JIS mix proportions that W/C was lowered result in the rank improved strength, the combination using the high-range water-reducing agent (type of $\mathrm{AE}$ ) in substitution for high-range water-reducing agent in consideration of elapsed time, these were targeted for inspection. W/C was set as same as mix proportions shipped for lining concrete, the slump of the aim assumed $15 \mathrm{~cm}$, the quantity of air $4.5 \%$. Except JIS mix proportions $(30-15-40 \mathrm{~N})$ that a rank improved strength.

TABLE VI: MIX PROPORTIONS (CASE III)

\begin{tabular}{|c|c|c|c|c|c|c|c|c|c|c|c|c|c|c|c|}
\hline \multirow[b]{2}{*}{ Case } & \multirow{2}{*}{$\begin{array}{c}\mathrm{W} / \mathrm{C} \\
(\%)\end{array}$} & \multirow{2}{*}{$\begin{array}{l}\text { Air } \\
(\%)\end{array}$} & \multirow[b]{2}{*}{ s/a (\%) } & \multicolumn{12}{|c|}{ Unit weight $\left(\mathrm{kg} / \mathrm{m}^{3}\right)$} \\
\hline & & & & $\mathrm{W}$ & $\mathrm{C}$ & $\mathrm{EX}$ & S3 & S4 & $\mathrm{G} 2$ & G3 & G4 & HA & HRWR & WRA & $\begin{array}{c}\text { HPW } \\
\text { RA }\end{array}$ \\
\hline III-(1) & \multirow{2}{*}{55.0} & \multirow{4}{*}{4.5} & \multirow{2}{*}{42.4} & \multirow{2}{*}{160} & 291 & 0 & \multirow{2}{*}{617} & \multirow{2}{*}{154} & \multirow{2}{*}{436} & \multirow{2}{*}{327} & \multirow{2}{*}{327} & \multirow{2}{*}{11.6} & \multirow{2}{*}{1.5} & \multirow{2}{*}{0} & \multirow{2}{*}{0} \\
\hline III-(2) & & & & & 256 & 35 & & & & & & & & & \\
\hline III-(3) & 47.0 & & 39.6 & 163 & 347 & 0 & 559 & 140 & 443 & 332 & 332 & 0 & 0 & 3.5 & 0 \\
\hline III-(4) & 55.0 & & 42.4 & 160 & 291 & 0 & 617 & 154 & 436 & 327 & 327 & 11.6 & 0 & 0 & 1.5 \\
\hline
\end{tabular}

TABLE VII: FRESH PROPERTY AND QUALITY AFTER THE HARDENING (CASE II)

\begin{tabular}{|c|c|c|c|c|c|c|c|c|c|c|}
\hline \multirow{2}{*}{ Case } & \multirow{2}{*}{ Admixture } & \multirow{2}{*}{$\begin{array}{l}\text { Slump } \\
(\mathrm{cm})\end{array}$} & \multirow{2}{*}{$\begin{array}{l}\text { Air } \\
(\%)\end{array}$} & \multirow{2}{*}{$\begin{array}{c}\text { Temperature } \\
\left({ }^{\circ} \mathrm{C}\right)\end{array}$} & \multicolumn{2}{|c|}{$\begin{array}{c}\text { Setting time } \\
(\mathrm{hr}-\mathrm{min})\end{array}$} & \multicolumn{4}{|c|}{$\begin{array}{c}\text { Compressive strength } \\
\left(\mathrm{N} / \mathrm{mm}^{2}\right)\end{array}$} \\
\hline & & & & & Initial & Final & $\begin{array}{c}18 \\
\text { hours }\end{array}$ & $\begin{array}{c}1 \\
\text { days } \\
\end{array}$ & $\begin{array}{c}7 \\
\text { days } \\
\end{array}$ & $\begin{array}{r}28 \\
\text { days }\end{array}$ \\
\hline I -(1) & - & 16.0 & 5.0 & 20.0 & $6-35$ & $11-00$ & 1.49 & 2.77 & 19.6 & 33.2 \\
\hline I -(2) & $\mathrm{CN}$ & 11.0 & 5.1 & 21.0 & $5-25$ & $8-55$ & 2.02 & 3.21 & 22.9 & 34.2 \\
\hline I -(3) & EX & 6.5 & 3.9 & 21.5 & $7-20$ & $11-40$ & 1.82 & 4.02 & 25.9 & 40.7 \\
\hline I -(4) & SM & 13.5 & 3.4 & 20.5 & $7-20$ & $11-30$ & 1.40 & 2.79 & 28.8 & 42.7 \\
\hline
\end{tabular}

\section{RESULTS AND DISCUSSION}

\section{A. Selection of Candidate Materials (Case I)}

Fresh property and Quality after the hardening are shown in Table VII. The slump in the fresh property aimed for around $15 \mathrm{~cm}$ in base Case I-(1)which assumed combination for tunnel lining concrete. As a result, In the combination that added the admixture which an improvement effect of the initial strength development could expect. A tendency that slump became smaller than base Case I-(1) was provided. As for the high-strength materials and hydration accelerator materials which expanded of powders, W/C in combination conditions constantly, the unit powders quantity of Case I-(3) and Case I-(4) increased in a part of fine aggregate and the thing that there were replaced than Case I- (1) and Case I(2), and the tendency that slump became small under the condition of the equivalence tall handloom ability high-performance water-agent (type of $\mathrm{AE}$ ) addition quantity became remarkable (in Case I- (3) $6.5 \mathrm{~cm}$ ). Therefore as a result of having added a lot high-performance water-reducing agent (type of AE) for $0.1 \%$ of quantity of unit cement in Case I- (4), the slump fitted into the range where $13.5 \mathrm{~cm}$ and an aim were near.

Effect of admixture on crackle value in Fig. 2, the compressive strength at the initial materials age in Fig. 3, Effect of admixture on compressive strength is shown in Fig. 4.In Case I- (1) using Corrosion inhibitor, the initial setting time of the condensation, final setting time became earlier together than base Case I- (1) for 1-2 hours. But, it followed that the initial setting time of the condensation, and were behind base Case I- (1) together adversely when other admixture were used.

On the other hand, in Case I an effect was relatively big about the compressive strength of the initial materials age by using the corrosion inhibitor of Case I- (2) and using hydration accelerator materials of Case I- (3). The result in the initial materials age, compressive strength of Case I- (2) is big at materials age 18 hours, Case I- (3) is higher in strength development at materials age 24 hours. However, the compressive strength of Case I- (2) does not change base Case I- (1) and when it is materials age after 7th. Strength development of Case I- (3) and Case I- (4) using high-strength admixture was given conspicuously, Thus, in Case I- (3), a strength development effect is accepted regardless of an examination materials age. Therefore, as for strength development being anticipated from an initial materials age with the combination using hydration accelerator materials. The result of drying shrinkage is shown in Fig. 5, for materials age 38 weeks, Dry shrinkage distortion of the combination using hydration accelerator materials does not grows big in compared to other combination in Case I.

\section{B. Simulation Test (Case II)}

After Case I, It was demanded to enable an early demolding of the lining concrete in specific tunnel construction. Because aim strength of $3 \mathrm{~N} / \mathrm{mm}^{2}$ was set to be concrete in materials age 10 hours, because it was unrealizable on the mix proportions of Case I, a kind of the cement, the mix proportions of admixture was changed. Fresh property and hardened property are shown in Table VIII. In Case II, as for the hydration accelerator materials, dosage was not changed in Case II- (1) and II- (2) by having substituted it with a part of the cement. As a result, in the slump in the fresh property, Case II- (2) using hydration accelerator material did not become small. The spacing effect with the high-range water-reducing agent was shown and in the quantity of same addition, the slump became rather big. About the compressive strength, strength development of Case II- (1) by the hydration accelerator and high-range 
water-reducing agent remained in materials age 10 hours $2.08 \mathrm{~N} / \mathrm{mm}^{2}$, and 12 hours to $2.53 \mathrm{~N} / \mathrm{mm}^{2}$, aim strength did not reached.

On the other hand, Case II- (2) of hydration accelerator materials the hydration accelerator in addition to an hydration accelerator materials and high-range reducing water agent of materials age 10 hours $3.05 \mathrm{~N} / \mathrm{mm}^{2}, 12$ hours $3.62 \mathrm{~N} / \mathrm{mm}^{2}$ and satisfied aim strength. But compressive strength more than $2 \mathrm{~N} / \mathrm{mm}^{2}$ having been provided at materials age 10 hours, it was judged from quality to find to lining concrete, the category that a demolding is possible enough. Besides some differences occur in the tendency to strength development of the concrete because of the difference used materials The additive consumption such as reduction of water agents may greatly varies according to aggregate properties of matter, in particular an influence on the strength development in the initial materials age. The mix proportions by the combination of hydration accelerator materials in addition to hydration accelerator and a high-range water-reducing agent were qualitatively advantageous to the strength development of the initial materials age. Mix proportions design was carried out in materials same as the plant which supplied lady mixed concrete to the tunnel construction site.

\section{On Site Confirmation Test (Case III)}

Inspection was carried out in the difference in strength development properties of the concrete with materials same as a plant to supply the tunnel construction concrete. Fresh property and Quality after hardening are shown in Table IX. The materials used were changed the consumption of the high-range reducing-water agent in Case II (it largely decreases from $3 \%$ of quantity of unit cement to $0.5 \%$ ), the slump of the aim was able to secure around $15 \mathrm{~cm}$. Furthermore, about the compressive strength, strength development of Case III-(1) by the combination of hydration accelerator and high range water reducing agent reaches $3.48 \mathrm{~N} / \mathrm{mm}^{2}$ in materials age 10hours. Case III-(1) was able to satisfy aim strength enough (naturally Case III-(2) by the combination of hydration accelerator materials reached $3.91 \mathrm{~N} / \mathrm{mm}^{2}$ more than Case III-(1) in addition to hydration accelerator and a high-range reducing water in materials age 10 hours, but material costs are enough in Case III-(1) becoming cheap) .

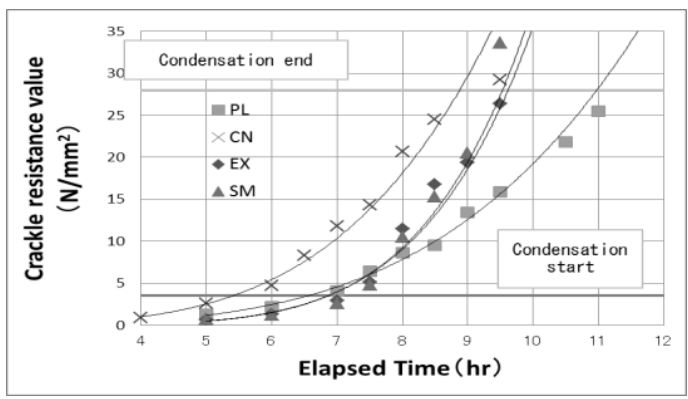

Fig. 2. Effect of admixture on crackle value.

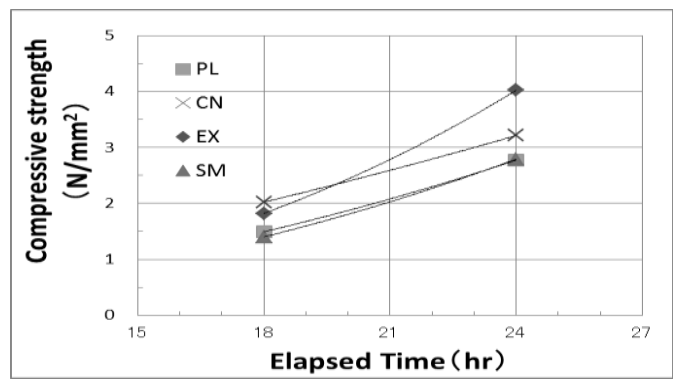

Fig. 3. Compressive strength at the initial materials age.

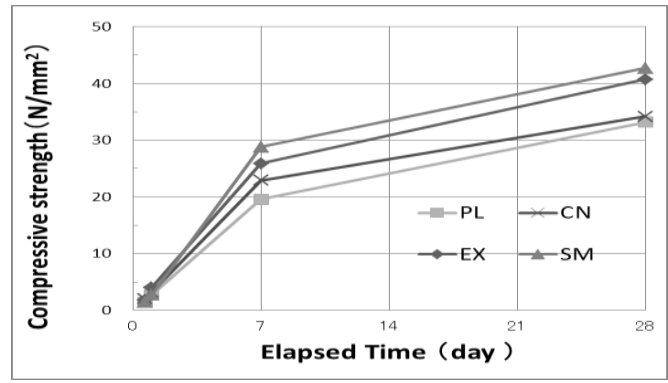

Fig. 4. Effect of admixture on compressive strength.

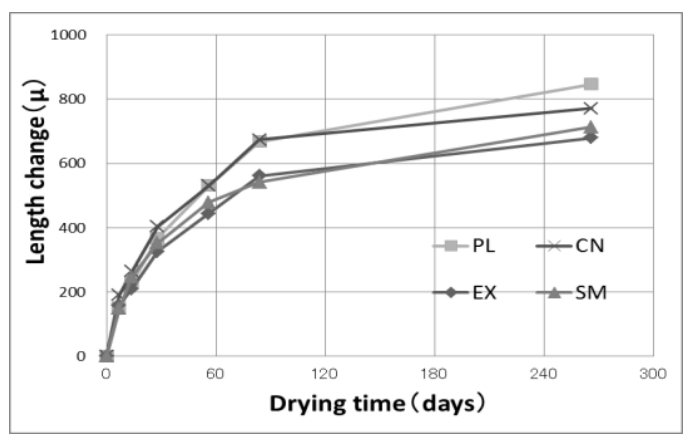

Fig. 5. Dry shrinkage test.

TABLE VIII: FRESH PROPERTY AND QUALITY AFTER HARDENING (CASE II)

\begin{tabular}{|c|c|c|c|c|c|c|}
\hline \multirow{2}{*}{ Case } & \multirow{2}{*}{ Admixture } & \multirow{2}{*}{ Slump $(\mathrm{cm})$} & \multirow{2}{*}{$\operatorname{Air}(\%)$} & \multirow{2}{*}{ Temperature $\left({ }^{\circ} \mathrm{C}\right)$} & \multicolumn{2}{|c|}{ Compressive strength $\left(\mathrm{N} / \mathrm{mm}^{2}\right)$} \\
\cline { 6 - 7 } & & & & 2.0 & 10hours & 2.08 \\
\hline II -(1) & HA & 14.5 & 3.5 & 21.0 & 2.08 & 2.53 \\
\hline II -(2) & HA +EX & 19.0 & 3.3 & 21.5 & 3.05 & 3.62 \\
\hline
\end{tabular}

TABLE IX: FRESH PROPERTY AND QUALITY AFTER HARDENING (CASE III)

\begin{tabular}{|c|c|c|c|c|c|c|c|c|c|c|c|}
\hline \multirow{2}{*}{ Case } & \multirow{2}{*}{$\begin{array}{l}\mathrm{W} / \mathrm{C} \\
(\%)\end{array}$} & \multirow{2}{*}{ Admixture } & \multicolumn{2}{|c|}{$\begin{array}{l}\text { Slump } \\
(\mathrm{cm})\end{array}$} & \multicolumn{2}{|c|}{$\begin{array}{l}\text { Air } \\
(\%)\end{array}$} & \multirow{2}{*}{$\begin{array}{l}\text { Temperature } \\
\left({ }^{\circ} \mathrm{C}\right)\end{array}$} & \multicolumn{4}{|c|}{ Compressive strength $\left(\mathrm{N} / \mathrm{mm}^{2}\right)$} \\
\hline & & & $\begin{array}{c}0 \\
\min \end{array}$ & $\begin{array}{c}30 \\
\text { min }\end{array}$ & $\begin{array}{c}0 \\
\text { min }\end{array}$ & $\begin{array}{c}30 \\
\text { min }\end{array}$ & & $\begin{array}{c}10 \\
\text { hours }\end{array}$ & $\begin{array}{c}11 \\
\text { hours }\end{array}$ & $\begin{array}{c}7 \\
\text { days }\end{array}$ & $\begin{array}{c}28 \\
\text { days }\end{array}$ \\
\hline III-(1) & \multirow{2}{*}{55.0} & HA+HRWR & 16.0 & 12.5 & 3.6 & 3.3 & 22.0 & 3.48 & - & 31.2 & 39.8 \\
\hline III-(2) & & Case III-(1)+EX & 19.0 & - & 3.3 & - & 22.0 & 3.91 & - & 28.3 & 36.4 \\
\hline IIII-(3) & 47.0 & HRA & 20.5 & - & 4.7 & - & 22.0 & 2.25 & - & 37.6 & 47.7 \\
\hline IIII-(4) & 55.0 & $\mathrm{HA}+\mathrm{HPWR}$ & 16.5 & 14.5 & 4.6 & 3.9 & 22.0 & 2.90 & 3.47 & 31.6 & 40.9 \\
\hline
\end{tabular}

However, 30 minutes after considered the elapsed time from a plant to the construction site; as a result of passing, and measured a change at time, in Case III-(1) of slump loss was big. In addition, Case III- (3) (aiming at $30 \mathrm{~N} / \mathrm{mm}^{2}$ 
equivalency) was prepared to a rank improved combination strength for a comparison. Strength development more than required will be provided in the long term when aim strength is provided in materials age 10 hours. This might be estimated as an excessive design, but the compressive strength was able to reached aim strength $3 \mathrm{~N} / \mathrm{mm}^{2}$ in Case III-(3)of materials age 10 hours $: 2.25 \mathrm{~N} / \mathrm{mm}^{2}$. Therefore, case III- (1) of the high-performance water reducing agent was changed of the high-range reducing-water (type of AE) to aimed at reduction of the slump loss. As a result, the slump loss 30 minutes later the range(from $16.5 \mathrm{~cm}$ to $14.5 \mathrm{~cm}$ loss of $2.0 \mathrm{~cm}$ ) permitted enough in Case III-(4) by the combination of and hydration accelerator and high-performance water reducing agent( type of $\mathrm{AE}$ ) .The compressive strength expression did not slightly reach to the aim strength in materials age 10hours: $2.90 \mathrm{~N} / \mathrm{mm}^{2}$ and, but reached $3.47 \mathrm{~N} / \mathrm{mm}^{2}$ in materials age 11 hours. But the unevenness of the compressive strength in materials age 10hours of Case III-(4) is small (the min of three test specimens $2.83 \mathrm{~N} / \mathrm{mm}^{2}$, the $\max 2.96 \mathrm{~N} / \mathrm{mm}^{2}$ ). When the grounds that set aim strength to $3 \mathrm{~N} / \mathrm{mm}^{2}$ here in materials age 10 hours are reviewed. the compressive strength of the concrete in the demolding often assumes around $2-3 \mathrm{~N} / \mathrm{mm}^{2}$ an [2] aim is written in concrete standard specifications [mountains method of construction] • the commentary.

Therefore, Demolding strength with on-site construction characteristics, Case III- (4) by the combination of hydration accelerator and high-performance water reducing agent(type of AE) is the usually most suitable for a base with Portland cement.

\section{CONCLUSION}

In this study, some materials in which an improvement effect of the initial strength development that the cycle time of concrete lining work in NATM can be reduced, were selected and evaluated. It was started to inspect the difference in strength development properties of the concrete.

Afterwards, specific tunnel construction site of the rapid construction of the lining concrete is necessary. The combination of materials that compressive strength satisfied aim strength of $3 \mathrm{~N} / \mathrm{mm}^{2}$ at the age of 10 hours was inspected. As a result, a use will extend an additive (accelerator) developed for a concrete product factory to ready mixed concrete. However, it was with an application at the low strength that was easy to be realized optimization of the productivity.

There is not the big trouble in producing it with a plant same as normal ready mixed concrete.

Various data collection concerning not only quality but durability at the upcoming construction work from now on is being planned and these data will be reported in the future.

\section{REFERENCES}

[1] H. Ito, I. Maruyama, and R. Sato, "Early age defomartion and resultant induced stress in expansive high strength concrete," Journal of Advanced Concrete Technology, vol. 2, no. 2. 155-174, Jun 2004.

[2] Japan Society of Civil Engineering: Tunnel concrete standard specifications [mountains method of construction], the commentary, pp. 173, (in Japanese), 2006.
[3] E. Sakai, T. Ansai, D. Atarashi, and Y. Ikeo, "Mterial design of high volume blast furnace slag cement ii consideration of early hy daration of cement," Cement Science and Concrete Technology, no. 65, 2011.

[4] M. Ikeda, C. Hashimoto, Y. Tsuji, and T. Sugiyama, "The influence that good self-care temperature and an early demolding give to initial strength of mortar," in Proc. the Collection of Japan Society of Civil Engineering 51st Annual Academic Lecture Summaries Fifth Section, 1996, pp. 524-525.

[5] N. Shiga, T. Misaka, H. Uno, and T. Shinomura, "One consideration about the initial strength development of the lining concrete for tunnels," in Proc. the Collection of Japan Society of Civil Engineering 69th Annual Academic Lecture Summaries Sixth Section, 2013, pp. 111-112.

[6] T. Yoshikawa, M. Hosokawa, and T. Tanaka, "MgO effect on hydrothermal solidification of blast furnace slag," ISIJ International, vol. 48, no. 5, pp. 557-562, 2008.

[7] S. Hoshino, K. Yamada, and H. Hirao, "XRD/rietveld analysis of the hydration and strength development of slag and limestone blended cement," Journal of Advanced Concrete Technology, vol. 4, no. 3. 357-367, Oct 2006.

[8] T. Saeki, K. Sasaki, and K. Shinada, "Estimation of chloride diffusion coefficent of concrete using mineral admixtures," Journal of Advanced Concrete Technology, vol. 4, no. 3, pp. 385-394, Oct. 2006.

[9] Y. Luan, T. Ishida, T. Nawa, and T. Sagawa, "Enhanced model and simulation of hydration process of blast furnace slag in blended cement," Journal of Advanced Concrete Technology, vol. 10, pp. 1-13, Jan. 2012.

[10] M. Satou, H. Minagawa, and M. Hisada, "Influence of mineral admixture on the hardening process of mortar with a focus on strength and permeability," Journal of the Society of Materials Science, vol. 62, no. 8 , pp. $479-485,2013$

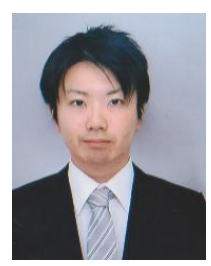

Shun Sasaki was born in Iwate Pref, Japan. He graduated from Tokai University in 2014, Japan. He is a student of graduate school of Tokai University, Japan.

His research interests include construction materials engineering,

Mr. Sasaki is a member of JCI, JSCE.

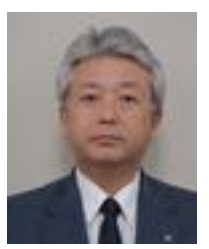

Yoshiki Uno was born in Tokyo Pref, Japan. He graduated from Waseda University in 1986. He received his doctor of engineering from Kanazawa Institute of Technology, Ishikawa Japan, in 2013. His major field of study is in concrete engineering, maintenance engineering. He is working for Sato Kogyo Co., ltd and he as a general manager, Department of Civil Engineering, Technical Research Institute, 14-10, Morinosato Aoyama, Atsugi Kanagawa Japan. His research interests include are risk management, maintenance, and prevention technology. Dr. Uno is a member of JCI, JSCE.

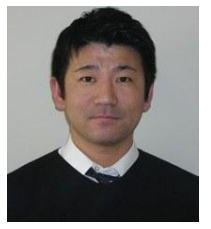

Shin-ichiro Hashimoto was born in Hiroshima Pref, Japan. He graduated from Maebashi Institute of Technology, Gumma Japan, in 2001. He received his doctor of engineering from Tokushima University, Tokushima Japan, in 2006. His major field of study is in concrete engineering. $\mathrm{He}$ is working for Fukuoka University and he as a assistant professor of Dept. of Civil Engineering, 8-19-1 Nanakuma, Jonan-ku, Fukuoka Japan. His research interests include material design, workability and pumpability of fresh concrete. Dr. Hashimoto is member of JCI, JSCE, AIJ.

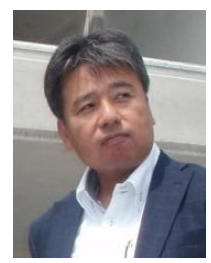

Shigeyuki Date was born in Fukuoka Pref, Japan. He graduated from Nagasaki University in 1987 and He received his doctor of engineering from Gumma University, Gumma Japan, in 2005. He is major field of study is in concrete engineering, maintenance engineering. He is working for Tokai University. as a professor of Department of Civil Engineering, 4-1-1 Kitakaname Hiratsuka Kanagawa Japan.

His research interests include material design, durability of concrete structure, concrete production, and pre-cast concrete. Dr. Date is a member of JCI, JSCE, AIJ, SMSJ. 